\title{
Kemampuan Representasi Matematis Siswa melalui Model Problem Based Learning pada Materi Lingkaran dengan Konteks Kepramukaan di SMP
}

\author{
Suaibatul Aslamiah, Rahmah Johar*, Erni Maidiyah \\ Universitas Syiah Kuala \\ *rahmah.johar@unsyiah.ac.id
}

\begin{abstract}
Mathematical representation ability is a useful ability for students to develop and optimize their mathematical abilities. The real situation shows that the importance of the ability of mathematical representation has not been matched by student achievement. This condition can be solved by applying problem based learning model to learning in a context that is familiar to students such as scouts. The aim of this research is to explain the ability of students' mathematical representation through the Problem Based Learning model with scouts context on circle material at SMPN 8 Banda Aceh. This research used qualitative approach with a type of research is descriptive. Data obtained through tests of student' mathematical representation abilities and interviews. The ability of students' mathematical representations was analyzed by utilizing the data obtained in student learning in groups through PBL model and data of result test after the application of PBL model. The achievement of this research is the ability of students' mathematical representation during learning with PBL model in groups is accordance with the ability of students' mathematical representation after applying the PBL model. The mathematical representation ability of high ability students is able to complete all of the indicators of the mathematical representation ability, students who are in the medium ability only complete indicators of visual and symbolic representation, and low ability students only able to complete indicator of visual representation, although not perfectly.
\end{abstract}

Keywords :Mathematical representation ability, Problem Based Learning model, Circle, Scouts

This is an open access article distributed under the Creative Commons 4.0 Attribution License, which permits unrestricted use, distribution, and reproduction in any medium, provided the original work is properly cited. $\odot 2019$ by author and Universitas Negeri Padang.

\section{PENDAHULUAN}

Pembelajaran matematika penting dipela jari siswa dengan harapan mereka mempunyai kemampuan matematis dan mampu meman faatkannya. Permendiknas Nomor 22 Tahun 2006 mengenai tujuan pembelajaran matematika butir keempat menyatakan pembelajaran matematika bertujuan agar siswa siswa mampu mengomunikasikan gagasan dengan simbol, tabel, diagram, atau media lain untuk memperjelas keadaan atau masalah (Depdiknas, 2006). Merujuk pada tujuan pembelajaran matematika di Indonesia butir keempat, kemampuan representasi matematis siswa diperlukan untuk mengomunikasikan semua kemampuan matematis yang dimilikinya (NCTM, 2000). Menurut Luitel (2017) kemam puan representasi matematis siswa berkaitan dengan cara yang digunakan siswa untuk menyajikan suatu permasalahan dengan meng gunakan bentuk yang berbeda, seperti meng gunakan simbol matematika, gambar, diagram, tabel, serta uraian kata-kata.

Pentingnya kemampuan representasi mate matis siswa tidak searah dengan realita yang terdapat di lapangan.Kenyataan ini didukung oleh penelitian yang dilaksanakan oleh Sulastri (2017) yang menyimpulkan bahwa kemampuan representasi matematis siswa masih rendah. Faktor yang mengakibatkan rendahnya kemam puan representasi matematis siswa salah satunya yaitu faktor guru dalam melaksanakan kegiatan pembelajaran yang tergolong kaku.Pembelajaran seperti ini tidak dapat menumbuhkan kemam puan representasi matematis siswa (Hutagaol, 2013). Proses pembelajaran di dalam kelas memiliki peran terhadap munculnya perma salahan kemampuan representasi matematis siswa. Penentuan strategi pembelajaran yang tepat akan membuat pembelajaran tercipta lebih efektif sehingga mencapai tujuan yang ditargetkan (Suprihatiningrum, 2016).

Model Problem Based Learning (PBL)dapat diaplikasikan dalam pembelajaran untuk menga tasi permasalahan kemampuan representasi matematis siswa karena dengan mengapli kasikan model ini siswa dapat berperan aktif selama pembelajaran melalui kegiatan menyelesaikan permasalahan dengan cara melengkapi informasi yang rumpang. 
Model PBL juga dapat membantu siswa dalam menyusun pengetahuan mereka sendiri, serta memungkinkan siswa untuk memiliki penyele saian yang beragam (Johar, 2016). Hal ini didukung oleh hasil penelitian Maghfirah (2017) di MTs Negeri Tungkop Aceh Besar yang mendapatkan hasil yaitu kemampuan represent tasi matematis siswa meningkat setelah diterapkan model PBL.

Salah satu ciri model pembelajaran PBL yaitu mengaitkan materi pembelajaran dengan masalah autentik atau konteks dunia nyata. Konteks bermakna situasi di mana masalah disisipkan. Kehadiran konteks memberikan peran penting sebagai titik permulaan bagi siswa untuk mempelajari konsep matematika dalam situasi yang nyata bagi siswa (Widjaja, 2013). Penggunaan konteks dalam pembelajaran dapat memudahkan siswa untuk memahami konsep pelajaran yang ada dan membantu siswa untuk memperoleh strategi penyelesaian masalah.

Berbagai penelitian sebelumnya yang menerapkan konteks dalam pembelajaran pernah dilakukan oleh Widyawati (2016) yang menerapkan konteks rumah limas pada materi sudut dan Fyhn (2008) yang menerapkan konteks memanjat pada materi sudut.Pada penelitian ini peneliti menggunakan konteks kepramukaan. Penggunaan konteks kepra mukaan digunakan karena pramuka merupakan kegiatan ekstrakurikuler wajib dalam kurikulum 2013, sehingga relevan dan familiar dalam kehidupan siswa. Konteks kepramukaan juga dapat digunakan untuk materi lingkaran karena lingkaran dapat dijumpai pada beberapa objek dan aktivitas dalam konteks kepramukaan, seperti pada kegiatan baris-berbaris, atribut seragam pramuka, sandi dan kode yang digunakan dalam pramuka, dan sebagainya.

Berdasarkan uraian di atas maka pertanyaan penelitian pada penelitian ini, yaitu: 1) Bagaimanakah kemampuan representasi matematis siswa selama pembelajaran secara berkelompok melalui model Problem Based Learning dengan konteks kepramukaan pada materi lingkaran di SMPN 8 Banda Aceh? dan 2) Bagaimanakah kemampuan representasi matematis siswa setelah penerapan model Problem Based Learning dengan konteks kepramukaanpada materi lingkaran di SMPN 8 Banda Aceh?

\section{METODE PENELITIAN}

Pendekatan dalam penelitian adalah pendekatan kualitatif jenis deskriptif. Penelitian dilakukan di kelas VIII-4 yang terdiri dari 17 siswa dengan subjek penelitian sebanyak enam siswa yang dipilih berdasarkan tingkat kemampuan representasi matematisnya. Instru men dalam penelitian ini berupa lembar kerja kelompok siswa, lembar tes kemampuan representasi matematis yang memuat tiga soal uraian dan lembar pedoman wawancara. Lembar kerja kelompok siswa diperlukan untuk menjawab kemampuan representasi matematis siswa secara berkelompok. Lembar tes digunakan untuk memperoleh data tentang kemampuan representasi matematis siswa pada materi lingkaran setelah proses belajar melalui model PBL. Wawancara dilakukan dengan tujuan untuk mendapatkan data yang lebih akurat dan jelas dari subjek penelitian tentang kemampuan representasi matematis.

Analisis data tes kemampuan representasi matematis dilakukan dengan tiga tahapan yaitu reduksi data, menyajikan data, dan menarik kesimpulan. Bentuk kegiatan reduksi data antara lain mengoreksi hasil tes setiap siswa untuk menentukan subjek penelitian yang akan diwawancarai serta mentranskrip hasil wawan cara dengan menyederhanakan susunan bahasanya terlebih dahulu. Proses pengoreksian hasil tes siswa didasarkan pada acuan penskoran kemampuan representasi matematis siswayang ditunjukkan pada Tabel 1.

Tabel 1. Rubrik Kemampuan Representasi Matematis Siswa

\begin{tabular}{|c|l|l|l|}
\hline Skor & \multicolumn{1}{|c|}{ Verbal } & \multicolumn{1}{c|}{ Visual } & \multicolumn{1}{|c|}{ Simbolis } \\
\hline 0 & \multicolumn{3}{|c|}{ Tidak terdapat Jawaban } \\
\hline \multirow{2}{*}{1} & $\begin{array}{l}\text { Penjelasan } \\
\text { disusun } \\
\text { secara } \\
\text { matematis } \\
\text { akan tetapi } \\
\text { masih salah }\end{array}$ & $\begin{array}{l}\text { Tidak } \\
\text { membuat } \\
\text { gambar/grafik, } \\
\text { tetapi } \\
\text { memperoleh } \\
\text { penyelesaian }\end{array}$ & $\begin{array}{l}\text { Membuat } \\
\text { model } \\
\text { matematika } \\
\text { namun masih } \\
\text { salah }\end{array}$ \\
\hline \multirow{2}{*}{2} & $\begin{array}{l}\text { Penjelasan } \\
\text { ditulis } \\
\text { secara } \\
\text { matematis } \\
\text { namun tidak } \\
\text { lengkap }\end{array}$ & $\begin{array}{l}\text { Membuat } \\
\text { gambar/grafik } \\
\text { namun tidak } \\
\text { sempurna }\end{array}$ & $\begin{array}{l}\text { Membuat } \\
\text { model } \\
\text { matematika } \\
\text { namun tepat, } \\
\text { terdapat } \\
\text { kesalahan } \\
\text { perhitungan }\end{array}$ \\
\hline
\end{tabular}

Tabel 1.bersambung 


\begin{tabular}{|c|c|c|c|}
\hline Skor & Verbal & Visual & Simbolis \\
\hline 3 & $\begin{array}{l}\text { Penjelasan } \\
\text { ditulis secara } \\
\text { matematis } \\
\text { dan logis, } \\
\text { namun tidak } \\
\text { tersusun } \\
\text { secara } \\
\text { sistematis }\end{array}$ & $\begin{array}{l}\text { Membuat } \\
\text { gambar/grafik } \\
\text { dengan } \\
\text { sempurna } \\
\text { namun salah } \\
\text { dalam } \\
\text { memperoleh } \\
\text { penyelesaian }\end{array}$ & $\begin{array}{l}\text { Membuat model } \\
\text { matematika dan } \\
\text { perhitungan } \\
\text { dengan tepat, } \\
\text { akan tetapi } \\
\text { penyelesaian } \\
\text { yang diperoleh } \\
\text { salah }\end{array}$ \\
\hline 4 & $\begin{array}{l}\text { Penjelasan } \\
\text { disusun } \\
\text { secara } \\
\text { matematis, } \\
\text { serta } \\
\text { tersusun } \\
\text { secara logis } \\
\text { dan } \\
\text { sistematis } \\
\end{array}$ & $\begin{array}{l}\text { Membuat } \\
\text { gambar/grafik } \\
\text { secara } \\
\text { lengkap serta } \\
\text { memperoleh } \\
\text { penyelesaian } \\
\text { yang tepat }\end{array}$ & $\begin{array}{l}\text { Membuat model } \\
\text { matematika dan } \\
\text { perhitungan } \\
\text { dengan tepat, } \\
\text { serta } \\
\text { memperoleh } \\
\text { penyelesaian } \\
\text { yang benar dan } \\
\text { lengkap }\end{array}$ \\
\hline
\end{tabular}

(Sumber: Aiman, 2014)

Penyajian data siswa dilakukan dengan menyusun hasil pekerjaan siswa yang disusun menurut obyek penelitian dan dikelompokkan bersama dengan hasil wawancara mereka untuk mempermudah penarikan kesimpulan.

Berdasarkan hasil tes kemampuan representasi matematis akan dipilih subjek penelitian yang terdiri dari enam orang siswa yang dikelompokkan menjadi dua siswa berkemampuan rendah, dua siswa berkemam puan sedang, dan dua siswa berkemampuan tinggi. Pemilihan subjek penelitian dilakukan dengan menggunakan pedoman yang disajikan pada Tabel 2.

Tabel 2. Pedoman Pengelompokkan Siswa

\begin{tabular}{|c|c|}
\hline $\begin{array}{c}\text { Interval nilai tes yang } \\
\text { diperoleh }\end{array}$ & Kategori \\
\hline $80 \leq$ Nilai yang diperoleh $\leq 100$ & Tinggi \\
\hline $65 \leq$ Nilai yang diperoleh $<80$ & Sedang \\
\hline $0 \leq$ Nilai yang diperoleh $<65$ & Rendah \\
\hline
\end{tabular}

(Sumber: Rofiki, 2013)

\section{HASIL DAN PEMBAHASAN}

Hasil penelitian disajikan sesuai dengan rumusan masalah dalam penelitian, yaitu untuk mendeskripsikan kemampuan representasi matematis siswa selama pembelajaran secara berkelompok melalui model Problem Based Learning dan setelah penerapan model tersebut dengan konteks kepramukaan pada materi lingkaran di SMPN 8 Banda Aceh.

1. Kemampuan representasi matematis siswa selama pembelajaran secara berkelompok melalui model PBL

Kemampuan representasi matematis siswa secara berkelompok disajikan dari dua kelompok yang dipilih yaitu kelompok Adan kelompok B. Kedua kelompok tersebut dipilih karena mampu menyelesaikan permasalahan tersebut lebih baik dibandingkan dua kelompok lainnya.

a. Kelompok A

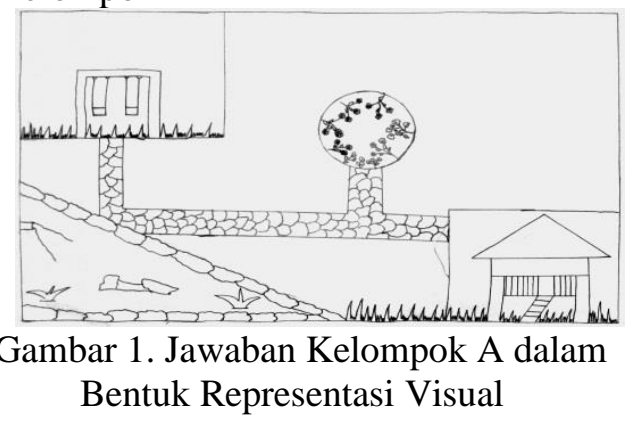

Ide penataan taman yang dibuat oleh kelompok A sangat kreatif dan memiliki kegunaan yang besar bagi masyarakat, namun denah taman yang ditata oleh kelompok A mencam puradukkan gambar dua dimensi dengan gambar tiga dimensi. Jadi, dapat disimpulkan bahwa kelompok A belum memenuhi indikator kemampuan representasi visual karena salah dalam mendapatkan solusi.

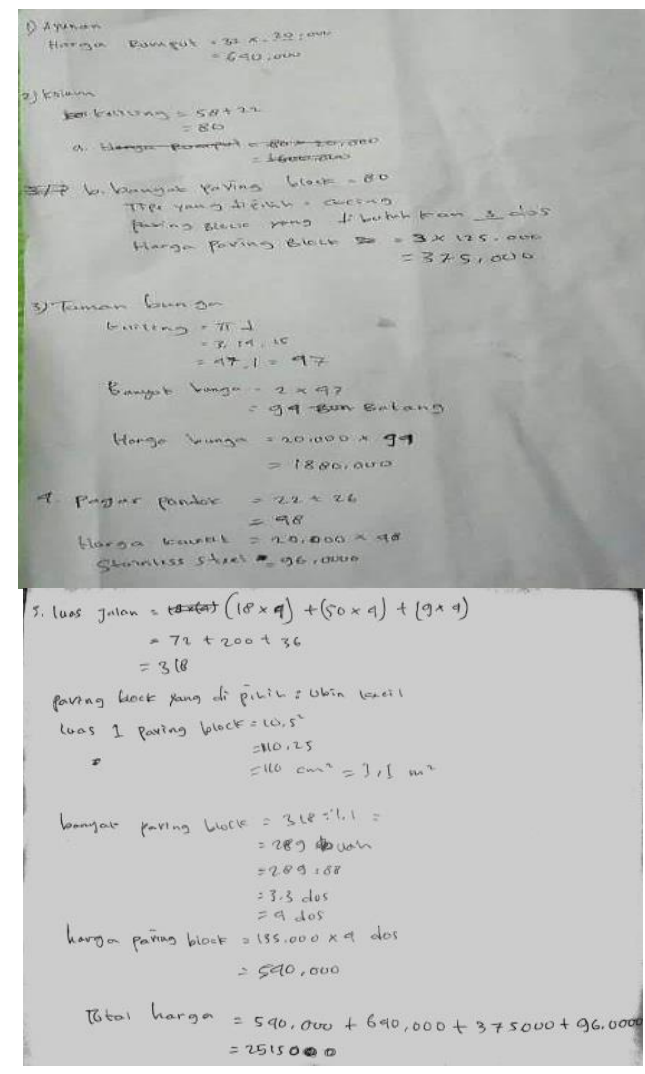

Gambar 2. Jawaban Kelompok A dalam Bentuk Representasi Simbolis

Jika diperhatikan, ternyata proses perhi tungan yang dilakukan oleh kelompok A 
terdapat kesalahan. Kesalahan proses perhi tungan tersebut diawali pada proses perhitungan luas jalan, sehingga solusi yang diperoleh juga salah.Berdasarkan uraian tersebut dapat disimpulkan bahwa kelompok A belum memenuhi indikator kemampuan representasi simbolis.

b. Kelompok B

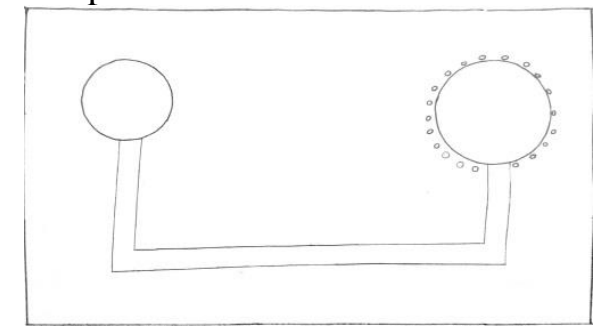

Gambar 3. Jawaban Kelompok B dalam

Bentuk Representasi Visual

Kelompok B sudah tepat memvisualisasikan denah taman yang mereka rancang dibandingkan dengan kelompok Aserta memperoleh penyelesaian yang tepat.Dengan demikian dapat disimpulkan bahwa kelompok B memenuhi indikator kemampuan representasi visual.

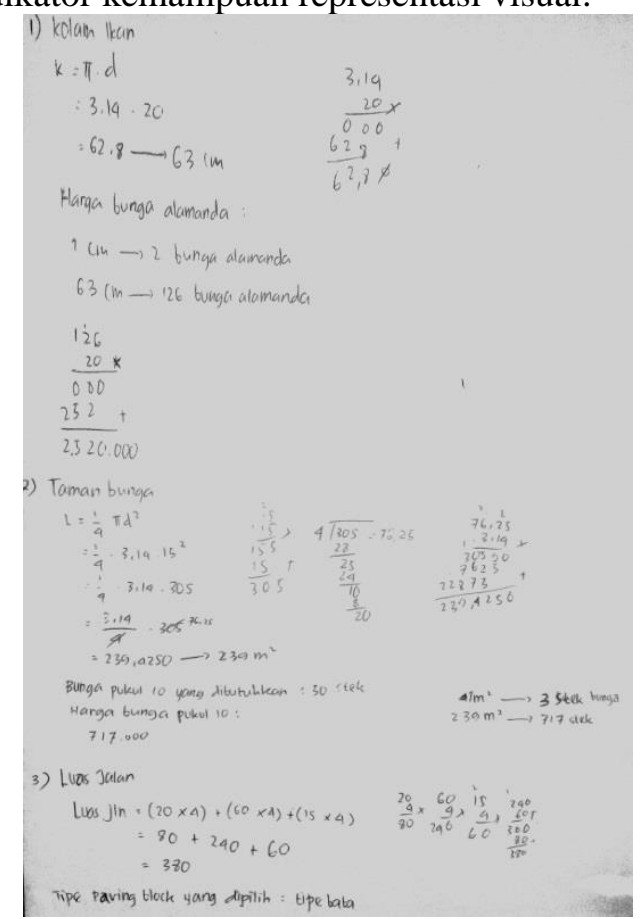

Gambar 4. Jawaban Kelompok B dalam

Bentuk Representasi Simbolis

Berdasarkan Gambar 3 diketahui bahwa kelompok $\mathrm{B}$ belum selesai mengerjakan permasalahan yang diberikan serta proses perhitungan yang dilakukan kelompok B juga terdapat kesalahan. Kesalahan tersebut terjadi pada proses mencari luas taman bunga tersebut.
Kesalahan kelompok B terletak pada proses mencari nilai kuadrat dari 15. Akibatnya proses perhitungan harga yang dibutuhkan untuk menata taman bunga tersebut juga mengalami kesalahan.Berdasarkan uraian tersebut dapat disimpulkan bahwa kelompok B belum memenuhi indikator kemampuan representasi simbolis.Berdasarkan penjelasan tersebut, dapat disimpulkan bahwa indikator kemampuan representasi visual kelompok B lebih baik dibandingkan dengan kelompok A, sedangkan indikator kemampuan representasi simbolis kelompok A lebih baik dibandingkan B.

2. Kemampuan representasi matematis siswa setelah penerapan model PBL

Berdasarkan analisis data maka dipilih enam siswa berdasarkan kriteria kemampuan representasi matematisnya yaitu siswa berke mampuan tinggi (CN dan IZ), siswa berkemam puan sedang (RM dan FR), dan siswa berkemampuan rendah (SA dan MZ).

a. Kemampuan representasi matematis siswa

$\mathrm{CN}$

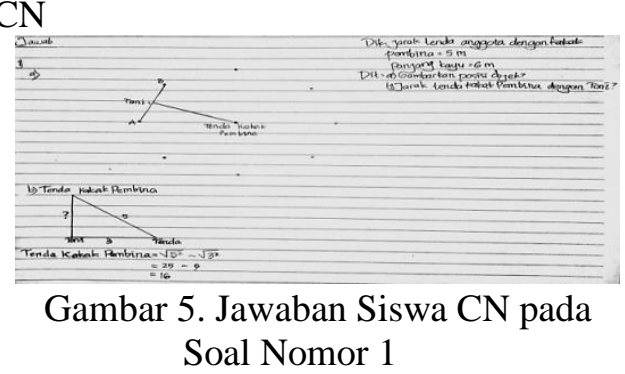

Siswa CN mampu merepresentasikan soal tersebut kedalam gambar dan model persamaan yang benar walaupun terdapat kesalahan dalam proses perhitungannya. Berikut petikan wawancara dengan siswa $\mathrm{CN}$ terkait jawaban soal nomor 1:

$P$ : Bisa kamu jelaskan mengapa kamu menjawab bagian b seperti ini?

$C N$ : Saya menggunakan aturan Phytagoras kemudian mengurangkan $25^{2}$ dengan $3^{2}$ dan hasilnya $25-9=16$

$P$ : Adakah yang ingin diubah atau ditambah dari jawabanmu?

CN : Oh iya bu hasilnya 4 karena hasil dari akar 16 adalah 4

Berdasarkan Gambar 6, siswa CN mampu menjawab soal nomor 2 dengan tepat serta melakukan perhitungan yang tepat. 


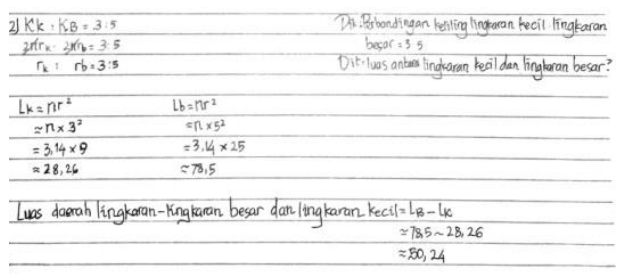

Gambar 6. Jawaban Siswa CN pada Soal Nomor 2

Petikan wawancara dengan siswa $\mathrm{CN}$ juga menyatakan ketepatan langkah yang diambil siswa $\mathrm{CN}$ untuk menyelesaikan permasalahan ini.

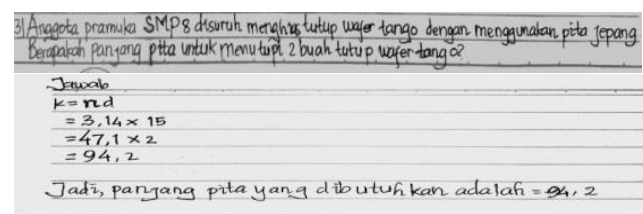

Gambar 7. Jawaban Siswa CN pada Soal Nomor 3

Mengacu pada Gambar 7, siswa CN ternyata belum menyelesaikan soal nomor 3 secara total. Hal ini dijelaskan pada petikan wawancara dengan siswa $\mathrm{CN}$ berikut:

$\mathrm{P}$ : Bagian manakah yang sulit menurutmu pada soal nomor 3 ini?

$C N$ : Ketika membuat soal cerita bu, bingung membuatnya

Jadi berdasarkan hasil tes dan wawancara yang dilakukan siswa $\mathrm{CN}$, maka dapat disimpulkan bahwa siswa $\mathrm{CN}$ dapat memenuhi ketiga indikator kemampuan representasi matematis siswa.

b. Kemampuan representasi matematis siswa IZ

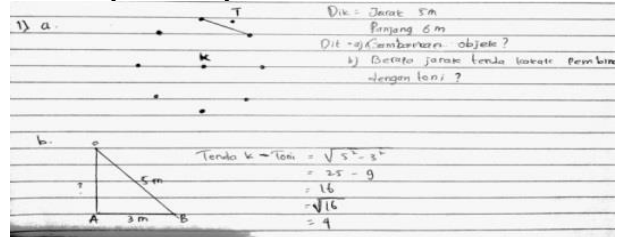

Gambar 8. Jawaban Siswa IZ pada Soal Nomor 1

Siswa IZ membuat kesalahan dalam meletakkan posisi Toni pada gambar.Secara keseluruhan jawaban IZ pada bagian b dapat dinyatakan sudah benar.

$P$ : Coba baca kembali jawabanmu, adakah bagian yang ingin kamu ubah atau tambah?

IZ : (melihat lembar jawaban) tidak ada bu
Berdasarkan petikan wawancara, siswa IZ sudah meyakini bahwa jawaban yang ia buat tidak salah. Jadi, berlandaskan hasil tes dan wawancara siswa IZ dapat ditarik kesimpulan bahwa kemampuan representasi visualnya belum mencapai indikator yang diinginkan, sedangkan kemampuan representasi simbolisnya sudah memenuhi.

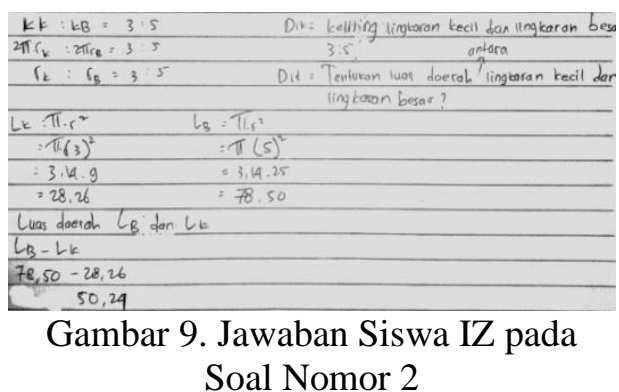

Siswa IZ mampu menyelesaikan soal nomor 2 dengan tepat serta melakukan perhitungan yang tepat.Petikan wawancara dengan siswa $\mathrm{CN}$ juga mendukung hal ini.Jadi berdasarkan hasil tes dan wawancara siswa $\mathrm{CN}$ menunjukkan kalau ia mampu memenuhi indikator kemampuan representasi simbolis.

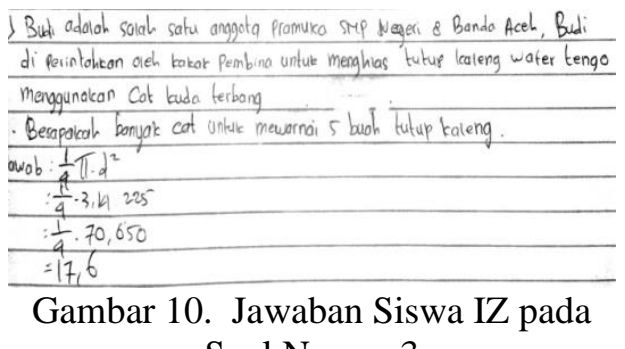
Soal Nomor 3

Berdasarkan Gambar 10, siswa IZ sudah mampu memenuhi indikator kemampuan representasi verbal dengan baik. Jadi dapat ditarik kesimpulan bahwa siswa IZ sudah memenuhi ketiga indikator kemampuan representasi matematis siswa.

c. Kemampuan representasi matematis siswa RM

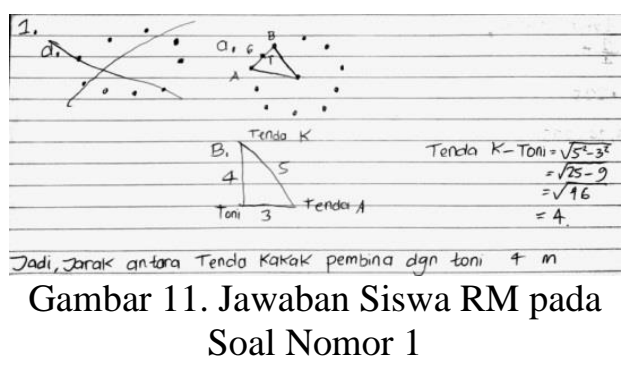

Siswa RM dapat merepresentasikan soal tersebut ke dalam bentuk gambar. Proses perhitungan 
yang dilakukan siswa RM juga dapat dinyatakan sudah benar.

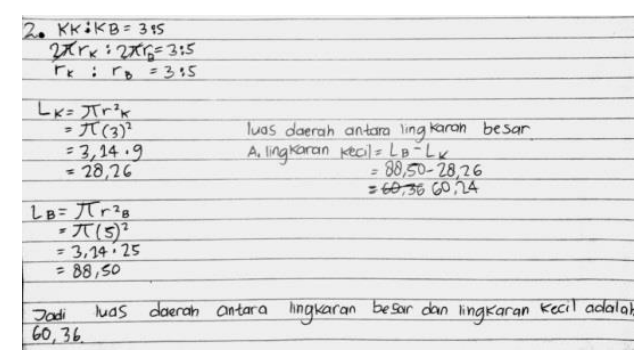

Gambar 12. Jawaban Siswa RM pada Soal Nomor 2

Siswa RM salah dalam melakukan perhitungan.Berdasarkan petikan wawancara tersebut diketahui bahwa kesalahan siswa RM dalam mendapatkan solusi yang benar dikarenakan kesulitannya dalam mengope rasikan perkalian angka.Berdasarkan jawaban tertulis siswa dan wawancara yang dilaksanakan, dapat ditarik kesimpulan bahwa siswa RM hanya mampu memenuhi indikator kemampuan representasi visual dan simbolis.

\section{d. Kemampuan representasi matematis} siswa FR

Mengacu pada jawaban siswa FR dalam soal nomor 1-3, maka ditarik kesimpulan bahwa kemampuan representasi matematis siswa FR tergolong mampu memenuhi indikator kemampuan representasi visual dan simbolis, dan hampir memenuhi indikator kemampuan verbal.

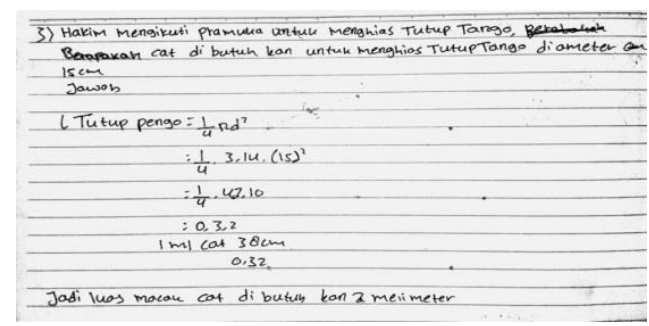

Gambar 13. Jawaban Siswa FR pada Soal Nomor 3

Solusi FR sesuai Gambar 12 menunjukkan kalau Ia belum mampu membuat cerita yang berkaitan dengan luas dan keliling lingkaran yang dihubungkan dengan konteks kepramukaan. Solusi yang diperoleh juga belum tepat dan benar terhadap soal cerita yang Ia buat.

e. Kemampuan representasi matematis siswa SA

Siswa SA dapat merepresentasikan soal pada nomor 1 menjadi representasi visual dan

representasi simbolis namun terdapat kesalahan.
Melalui proses wawancara diketahui bahwa SA tidak meyakini bahwa jawaban yang ia buat sudah benar.

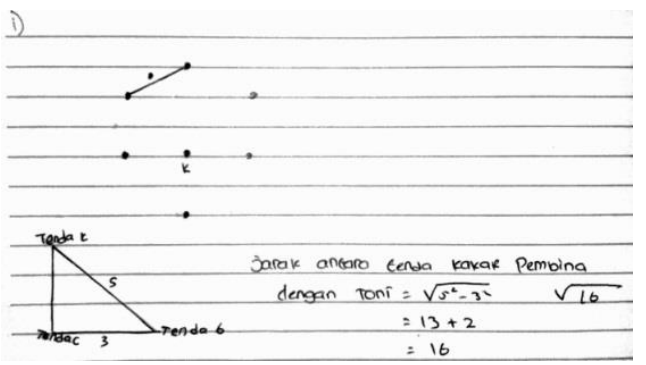

Gambar 14. Jawaban Siswa SA pada Soal Nomor 1

Jadi, mengacu pada hasil tes dan wawancara maka dinyatakan bahwa siswa SA belum mencapai indikator kemampuan representasi visual dan simbolis.

f. Kemampuan representasi matematis siswa MZ

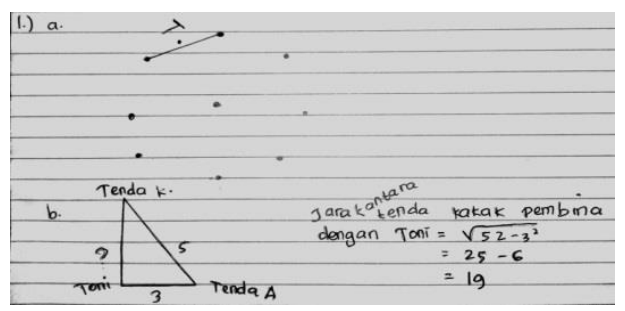

Gambar 15. Jawaban Siswa MZ pada Soal Nomor 1

Siswa MZ mampu membuat penyelesaian masalah dengan gambar, namun ia belum mampu membuatnya secara lengkap dan benar. Perhitungan yang dilakukan siswa IZ juga sudah menggunakan model matematika yang tepat, akan tetapi solusi yang dihasilkan masih salah. Jadi, siswa IZ hampir memenuhi indikator kemampuan representasi visual.

Hasil analisis kemampuan representasi matematis siswa selama pembelajaran dengan menerapkan model PBL menunjukkan bahwa pembelajaran dengan menggunakan model PBL membutuhkan banyak waktu dalam proses pelaksanaannya. Hal ini ditunjukkan dari hasil jawaban kelompok B yang belum selesai dalam melaksanakan perhitungan serta adanya dua kelompok siswa yang tidak dapat menyelesaikan permasalahan tersebut.Kenyataan ini sesuai dengan penelitian yang dilaksanakan oleh Akinoglu dan Tandogan (2007) yaitu pembelajaran dengan menerapkan model PBL membutuhkan waktu yang banyak.

Siswa dengan kemampuan representasi matematis tinggi ( $\mathrm{CN}$ dan IZ) mampu 
memenuhi ketiga indikator kemampuan representasi matematis, namun siswa $\mathrm{CN}$ mengalami kesulitan dalam representasi simbolis dan kelemahan siswa IZ terdapat pada representasi visual.Siswa berkemampuan sedang (RM dan FR) hanya mencukupi dua indikator kemampuan representasi matematis yaitu simbolis dan visual dengan kelemahan siswa RM terdapat pada representasi simbolis dan FR mengalami kesulitan dalam membuat represen tasi verbal. Sedangkan siswa berkemampuan rendah hanya memenuhi satu indikator kemampuan representasi matematis yaitu visual walaupun tidak secara sempurna.

Kemampuan representasi matematis siswa CN, RM, FR, SA, dan MZ berdasarkan jawaban tertulis pada tes kemampuan representasi matematis sejalan dengan kemam puan representasi mereka selama pembelajaran secara berkelompok. Keberhasilan mereka dalam proses pembelajaran secara berkelompok juga mengakibatkan bagusnya hasil tes yang diperoleh di akhir pembelajaran, begitu juga sebaliknya jika mereka gagal dalam proses pembelajaran maka hasil tes yang diperoleh juga buruk (Putriana, 2013).

Siswa yang berhasil pada hasil belajar belum tentu berhasil pada pembelajaran secara berkelompok.Hal ini dialami oleh siswa IZ.Siswa IZ merupakan siswa berkemampuan representasi matematis tinggi berdasarkan hasil analisis nilai tes, namun bertolak belakang dengan kemampuan representasi matematis IZ selama pembelajaran secara berkelompok. Perbedaan kemampuan representasi matematis siswa IZ selama KBM secara berkelompok dan pada tes dikarenakan siswa IZ lebih suka belajar secara sendiri.Kondisi ini sesuai dengan yang diutarakan oleh Sari (2012) yaitu terdapat siswa yang mengalami kesulitan dalam belajar secara berkelompok.

\section{KESIMPULAN}

Simpulan dari penelitian ini, yakni 1) kemampuan representasi matematis siswa selama pembelajaran melalui model PBL secara berkelompok sejalan dengan tingkat kemam puan representasi matematisnya pada tes, namun terdapat siswa yang mengalami kesulitan dalam belajar kelompok walaupun berhasil pada tes. Hal ini dikarenakan siswa tersebut mengalami kesulitan berkomunikasi dan bersosialisasi dengan anggota kelompok, 2) siswa berkemam puan representasi matematis tinggi dapat memenuhi ketiga indikator kemampuan representasi matematis, siswa berkemampuan sedang hanya memenuhi indikator kemampuan representasi visual dan simbolis, sedangkan siswa berkemampuan rendah hanya memenuhi indikator kemampuan representasi visual walaupun tidak sempurna.Berdasarkan simpulan tersebut maka disarankan pada penelitis elanjutnya untuk mengembangkan model PBL dengan konteks lain yang dekat dengan keseharian siswa.

\section{DAFTAR PUSTAKA}

Aiman, U. (2014). Pendekatan Pembelajaran Model Eliciting Activities (MEAs) Terhadap Kemampuan Representasi Matematis Siswa.(Skripsi, Universitas Islam Negeri Syarif Hidayatullah, 2014).

Akinoglu, O., \& Tandogan, R.O. (2007). The Effects of Problem Based Active Learning in Science Education on Students' Academic Achievement, Attitude and Concept Learning. Eurasia Jornal of Mathematics, Science, \& Technology Education, 3(1), 71-81.

Depdiknas.(2006). Standar Isi untuk Satuan Pendidikan Dasar dan Menengah. Jakarta.

Fyhn, A.B. 2010. Climbing and Angles: A Study of how two Teachers Internaliseand Implement the Intentions of a Teaching Experiment. Educational Studies in Mathematics, 67(1), 19-35.

Hutagaol, K. (2013). Pembelajaran Kontekstual untuk Meningkatkan Kemampuan Representasi Matematis Siswa Sekolah Menengah Pertama.Jurnal Ilmiah Program Studi Matematika STKIP Siliwangi Bandung, 2(1), 86-99.

Johar, R. (2016). Strategi Belajar Mengajar. Yogyakarta: Deepublish.

Luitel, B.C. (2017). Representation: Revisited. Australia: Curtin University of Technology.

Maghfirah, R. (2017). Peningkatan Kemampuan Representasi dan Disposisi Matematis Siswa MTsN melalui Penerapan Model Problem Based Learning. (Thesis, Universitas Syiah Kuala, 2017).

National Council of Teachers of Mathematics (NCTM). 2000. Principles and Standards 
for School Mathematics. United States of America.

Rofiki, I. (2013). Profil Pemecahan Masalah Geometri Siswa Kelas Akselerasi SMP Ditinjau dari Tingkat Kemampuan Matematika.Surabaya: UNESA.

Putriana, S. (2013).Pengaruh Belajar Kelompok dan Motivasi Belajar Siswa Terhadap Prestasi Belajar Siswa Kelas VIII SMP Negeri 23 Purworejo.Jurnal Oikonomia, 2(4), 325-330.

Sari, S.W. (2012). Pengaruh Model Pembelajaran dan Tipe Kepribadian Terhadap Hasil Belajar Fisika pada Siswa SMP Swasta di Kecamatan Medan Area. Jurnal Tabularasa PPS UNIMED, 9(1), 33-44.
Sulastri.(2017). Kemampuan Representasi Matematis Siswa Kelas VII SMP melalui Pendekatan Matematika Realistik. (Thesis, Universitas Syiah Kuala, 2017).

Suprihatiningrum, J. (2016). Strategi Pembela jaran: Teori \& Aplikasi. Jogjakarta: Arruzz Media.

Widjaja, W. (2013).The Use of Contextual Problems to Support Mathematical Learning.IndoMS-JME, 4(2), 151-159.

Widyawati, W., Putri, R. I. I., Somakim.(2016). Desain Pembelajaran Sudut Menggunakan Konteks Rumah Limas di Kelas VII. JINoP (Jurnal Inovasi Pembelajaran), 2(2), 437-448. 